\title{
IS BANK SUPERVISION CENTRAL TO CENTRAL BANKING?**
}

\author{
Joe Peek
}

Eric S. Rosengren

Geoffrey M. B. Tootell

\begin{abstract}
Recently, several central banks have lost their bank supervisory responsibilities, in part because it has not been shown that supervisory authority improves the conduct of monetary policy. This paper finds that confidential bank supervisory information could help the Board staff more accurately forecast important macroeconomic variables and is used by FOMC members to guide monetary policy. These findings suggest that the complementarity between supervisory responsibilities and monetary policy should be an important consideration when evaluating the structure of the central bank.
\end{abstract}

(JEL Codes: E52 E58)

*Valuable research assistance was provided by Faith Kasirye-Nsereko, Rokeya Khan, and Jonathon Willis. We thank Olivier Blanchard, Lynn Browne, Jeffrey Fuhrer, John Jordan, Richard Kopcke, Alexander Vamosi, and an anonymous referee for helpful comments. The views expressed are those of the authors, and do not necessarily reflect official positions of the Federal Reserve Bank of Boston or the Federal Reserve System. 
While the importance of central bank independence for the conduct of monetary policy has been the subject of numerous empirical studies (see, for example, Cukierman [1992]; Alesina and Summers [1993]; Posen [1995]; and Fuhrer [1997]), relatively little research has focused on the significance of other aspects of the structure of the central bank, particularly its role in bank supervision. Recently, however, this role has received increased attention from policymakers. Although roughly three-quarters of OECD nations assign their central banks either total or shared responsibility for bank supervision, many of these countries are reviewing those responsibilities. For example, in mid-1997 the Bank of England was given greater independence, but was stripped of its bank supervisory responsibilities. Policymakers in Japan, Korea, and Thailand are considering removing the central bank from bank supervision, and current plans include no direct role in bank supervision for the European Central Bank. One key element of the debate about whether the central bank retains, or is given, bank supervisory duties is whether these responsibilities contribute to the performance of monetary policy.

The United States has not been exempt from this controversy. Although the Federal Reserve System currently has partial responsibility for bank regulation and supervision, since 1994 a series of bills before Congress have proposed consolidating all bank supervisory responsibilities under a new single federal regulator, separate from the Federal Reserve. Proponents of such legislation have argued that bank supervision only distracts the Federal Reserve from its central task of conducting monetary policy. ${ }^{1}$ In contrast, opponents have argued that the central bank's role as lender of last resort and its responsibilities for crisis management require bank supervisory authority. We take a different approach, examining whether bank supervisory responsibilities improve the conduct of monetary policy. These responsibilities would improve monetary policy if 
the information obtained from the bank supervisory function improved the ability of the central bank to forecast the future path of the economy. This paper finds that bank supervisory information can and does help the Federal Reserve conduct monetary policy more effectively.

There are two major reasons one might expect bank supervisory information to improve economic forecast accuracy and thus contribute to effective monetary policy. First, problems in the banking sector may serve as an early indicator of deteriorating conditions in the macroeconomy generally. Alternatively, the information could provide advance notice of changes in bank lending behavior, which would affect the macroeconomy to the extent that the lending view is operative (see, for example, Bernanke and Gertler [1995]; Hubbard [1995]; Kashyap and Stein [1994a, 1994b]; and Kashyap, Stein, and Wilcox [1993]). Distinguishing which of these two reasons is most important is beyond the scope of this paper; instead, we investigate whether this information is used by the Federal Reserve in the conduct of monetary policy.

The Federal Reserve could effectively incorporate the bank supervisory information into monetary policy deliberations in two ways. First, the information could be used by internal Federal Reserve staff to improve their macroeconomic forecasts that are key to guiding policy actions. However, we find that it is not incorporated in this way, despite being highly correlated with private forecast errors of inflation and unemployment rates. Second, supervisory information could directly influence the decisions made by the Governors and Reserve Bank Presidents, who adjust the staff forecasts to reflect their own knowledge of banking problems. We find that it does, and in the direction implied by the forecast errors. These results are quite robust to alternative specifications, alternative time periods, and different subsets of Federal Open Market Committee (FOMC) members. 
We also find that it is the confidential component of the bank supervisory information that is correlated with these forecast errors. Thus, improving the accuracy of these forecasts requires access to confidential bank supervisory information. Even so, it is unclear that the FOMC needs "hands on" supervisory responsibilities, since the information could be transferred to the Federal Reserve from another bank supervisory agency. We provide suggestive evidence that direct supervisory authority may be useful, since examination data are likely to require interpretation as the process of collecting and evaluating the supervisory information evolves. As an example, we show that supervisory information on the largest banks both improves the forecasts and affects FOMC voting differently than information on smaller banks, possibly because regulators were reluctant to issue the lowest ratings and the consequent public enforcement actions to the largest banks. Such information is likely to be lost with only summary data, for the same reason that an econometrician can only approximate the information obtained more directly through the supervisory process.

The next section of this paper examines whether internal staff forecasts produced by the Federal Reserve incorporate confidential bank supervisory information. The second section considers whether this supervisory information directly affects monetary policy decisions by the FOMC. The third section addresses the question of whether the Federal Reserve should be directly involved in bank regulation or whether transferring summary statistical data is sufficient. The final section concludes.

\section{Does Supervisory Information Improve Federal Reserve Forecasts?}


The Federal Reserve obtains bank supervisory information in many ways. First, the

Federal Reserve is the primary regulator for state-chartered banks that are members of the Federal Reserve System and for all bank holding companies, which encompass the largest banking groups in the country. Second, Federal Reserve examiners frequently conduct joint exams with examiners from the Office of the Comptroller of the Currency (OCC), the primary regulator of banks with national bank charters; with the Federal Deposit Insurance Corporation (FDIC), the primary regulator of banks that are state-chartered but not members of the Federal Reserve System; and with state examiners. This cooperative work provides information both on banks for which the Federal Reserve is not the primary regulator and on examination procedures at other regulatory agencies. Third, the Federal Reserve receives exam reports and ratings from all other regulators.

While no single measure can capture the full set of information garnered by the examination process, a good proxy for the information on the most deeply troubled banks is the percentage of bank assets held by banks that are viewed by bank regulators as most likely to fail, those with a "CAMEL" rating of 5. These ratings are intended to reflect different degrees of bank health, with examiners rating each bank according to its Capital, Asset, Management, Earnings, and Liquidity (CAMEL). ${ }^{2}$ The ratings range from 1 , indicating no significant examiner concerns, to a rating of 5, indicating examiners believe that the bank has a high probability of failure.

Because an announcement by a regulator that a bank has a high probability of failure could be extremely detrimental to the institution, individual bank CAMEL ratings are highly classified. Not only are these ratings not available to the public, they are available only on a "need-to-know" basis within the Federal Reserve System. Bank examination staff, the Board of Governors, and 
the Presidents of Reserve Banks are aware of CAMEL ratings because of their work supervising examination staff, approving regulatory actions at troubled institutions, and considering safety and soundness issues as part of any bank acquisition or merger. ${ }^{3}$ However, most research staff at the Board of Governors and at the regional Reserve Banks do not have access to the data, including most of the staff responsible for generating the Greenbook forecasts used by the FOMC.

Results in Peek, Rosengren, and Tootell [1998] suggest that bank supervisory information is both confidential and important, since such data are shown to contain additional information about future unemployment and inflation rates beyond that incorporated in private forecasts. This section examines whether this confidential supervisory information is incorporated by Federal Reserve staff in forecasts of quarterly inflation rates and unemployment rates differently than by private forecasters, which do not have access to the confidential information. An important question is whether this information is fully incorporated in Greenbook forecasts.

To examine whether supervisory information is incorporated at some stage into the Board staffs economic outlook, we focus on forecasts of the Consumer Price Index (CPI) inflation rate and the unemployment rate. These variables are selected for two reasons. First, most of the literature modeling Federal Reserve objective functions specify these two variables as the ultimate targets of monetary policy (from, for example, Theil [1964] to Kydland and Prescott [1977] and Walsh [1995]). Second, and perhaps more important, inflation and unemployment rates are generated by surveys, and thus are not subject to large revisions. ${ }^{4}$

In order to compare Greenbook forecasts with those of private forecasters, several of which are provided only during the middle month of each quarter, we construct a quarterly data base that includes a single FOMC forecast per quarter. Because the FOMC meets more often 
than once per quarter, for each quarter we choose the Greenbook forecast dated closest to the middle of the quarter. The panel data set includes Greenbook forecasts as well as those from three major commercial forecasters: Data Resources, Inc. - McGraw Hill (DRI), Georgia State University (GSU), and the University of Michigan Research Seminar in Quantitative Economics (RSQE). We examine private sector and Greenbook forecasts for one-, two-, three-, and fourquarter-ahead forecasts of unemployment and inflation rates. Thus, for the middle month of each quarter, we look at each of the next four non-overlapping quarterly forecasts. For example, for the first quarter 1990 observation (forecasts provided in February), forecasted values for the first, second, third, and fourth quarters of 1990 would correspond to the one-, two-, three- and fourquarter-ahead forecasts.

Using a panel data set that pools quarterly observations for the four forecasters $(j=D R I$, GSU, RSQE, Greenbook), we estimate equations for each forecast horizon ( $\mathrm{i}=$ one-, two-, three-

$$
X_{t+i}=\alpha_{0}+\alpha_{1 t} X_{j, t+i}^{e}+\alpha_{2} C A M E L 5_{t}+\alpha_{3} G B * C A M E L 5_{t}+\varepsilon_{j, t+i}
$$

and four-quarter-ahead forecasts) of the form, This equation is estimated for the unemployment rate and for the CPI inflation rate. For each forecaster, we compare the actual value $(\mathrm{X})$ in quarter $\mathrm{t}+\mathrm{i}$ with the forecast for the corresponding quarter as of time $t\left({ }_{t} \mathrm{X}_{\mathrm{j}}^{\mathrm{e}}\right)$.

The percentage of bank assets held by banks with a supervisory composite CAMEL rating of 5 (CAMEL5) is a proxy for the information obtained through bank supervision. Given the breadth of information acquired in the supervisory process, one should not expect a single statistic such as CAMEL5 to fully capture that knowledge. For example, the CAMEL5 statistic alone 
does not provide knowledge of how supervisory ratings and actions may vary over time, location, and regulator, something that can be known only by participants in the supervisory process. Thus, CAMEL5 serves as an imperfect proxy for the broader set of information available to bank supervisors that is not easily quantified.

The supervisory information variable is measured as of the month prior to the forecast date (for example, the CAMEL5 that corresponds to the forecasts made in the middle of the first quarter would be as of the end of January). We also include an interactive term composed of the product of CAMEL5 and GB, a $(0,1)$ dummy variable that has a value of one for Greenbook forecasts and is zero otherwise. The estimated coefficient on this interaction term can be used to measure the extent to which the Greenbook outlook incorporates the CAMEL5 information differently than do the private forecasts.

If Greenbook forecasts do not differ from private forecasts in the degree to which the supervisory information is incorporated, $\alpha_{3}$ in equation (1) would not differ significantly from zero. On the other hand, if the supervisory information is fully utilized by the Greenbook, the estimated value of $\alpha_{3}$ would be significant and equal to $-\alpha_{2}{ }^{5}$

The structure of errors estimated in equation 1 is complicated. For example, an error in the four-quarter-ahead forecast made at time $t$ due to a shock subsequent to time $t$ will tend to be correlated with the error from the four-quarter-ahead forecast made at time $\mathrm{t}$-1, suggesting the possibility of a moving average in the error term. As a result, we correct for any moving average in the error term over the two-, three-, and four-quarter-ahead forecast horizons. ${ }^{6}$ Because the forecasters know the actual values for the inflation and unemployment rates for the prior quarter by the middle of the quarter, no moving-average (MA) correction is necessary for the one- 
quarter-ahead forecasts. It is also likely that individual forecast errors are contemporaneously correlated across forecasters because of shocks to the economy unanticipated by all the forecasters. For this reason, standard errors are corrected for contemporaneous correlations at each horizon, following the procedure described by Keane and Runkle [1990].

Table I provides the results from estimating equation 1. Consistent with the results in Peek, Rosengren, and Tootell [1998], the estimated coefficients on CAMEL5 in the unemployment rate equations are positive and significant at each forecast horizon. A positive coefficient indicates that a higher percentage of assets in CAMEL 5-rated banks is associated with a higher unemployment rate relative to its forecast value; in fact, an increase in CAMEL5 of 1 percentage point, roughly one standard deviation, would account for an underestimation of the four-quarter-ahead unemployment rate in excess of one-quarter of a percentage point. The estimated coefficient on CAMEL5 interacted with the Greenbook dummy variable is insignificant for each of the four forecast horizons. Not only are the t-statistics small, but the coefficient values are close to zero. Thus, the hypothesis that Greenbook and private unemployment rate forecasts fail to incorporate the confidential bank supervisory information to the same degree cannot be rejected. ${ }^{7}$

In fact, when the equation is respecified, replacing CAMEL5 with (1-GB)*CAMEL5 to directly test whether the CAMEL5 coefficients differ significantly from zero for the Greenbook forecasts, the estimated size of the coefficients and their significance levels are roughly the same as those for the private forecasts shown in the table. This is consistent with confidential supervisory information being highly useful in predicting unemployment rates, but not being used either by private forecasters or by the Board staff in preparing the Greenbook. 
For the inflation rate, the estimated coefficients on CAMEL5 are negative for each of the four horizons, significant at the 10 percent level for the one-quarter-ahead-forecast, the 5 percent level for the three-quarter-ahead forecast, and the 1 percent level for the four-quarter-ahead forecast. The coefficients are economically important, with a 1 percentage point increase in CAMEL5 producing an overestimate of the four-quarter-ahead inflation rate of 1.33 percentage points. As was the case in the unemployment rate equations, the estimated coefficients on GB*CAMEL5 are small relative to those on CAMEL5 and statistically insignificant for each forecast horizon. When we respecify the equation replacing CAMEL5 with (1-GB)*CAMEL5, the estimated effects of CAMEL5 for the Greenbook forecasts are of the same size and significance levels as those for private forecasts.

Because Federal Reserve staff typically do not have access to the confidential supervisory data, the failure to incorporate this confidential information into the Board staff forecasts is not surprising. The Greenbook outlook is actually a group of many component forecasts, using a combination of judgment and modeling, coordinated by senior staff to ensure consistency. Fully incorporating bank supervisory information in the Greenbook would require its widespread dissemination, placing its confidentiality at risk.

The fact that commercial forecasters do not fully exploit the information contained in CAMEL5 is not sufficient to establish that the estimated effect emanates solely from the confidential information contained in CAMEL5. These forecasts could be inefficient, for example, if the publicly available component were driving the results in Table I. If so, this evidence would not serve as a justification for Federal Reserve supervisory responsibilities, since the publicly available data might be sufficient for helping to guide monetary policy. 
CAMEL ratings almost certainly incorporate some publicly available information, since many of the factors that help determine the CAMEL ratings, such as capital ratios, nonperforming loans, and loan losses, are released to the public with various lags. However, because examination reports are more timely and examiners have access to a bank's proprietary information, some of the relevant information in the CAMEL ratings is unknown to the public.

To ensure that the confidential component of the supervisory data is responsible for our results, publicly available data useful in measuring bank health and in predicting CAMEL ratings are included as additional explanatory variables in equation 1. Promising candidates for inclusion are variables used in off-site monitoring by bank supervisors and private bank analysts. Generally, off-site monitoring is conducted by evaluating the bank's capital, assets, liquidity, and earnings (CAEL). These same variables are frequently used in studies to forecast CAMEL ratings and bank failures [Thomson 1991; Whalen and Thomson 1988; and Peek and Rosengren 1997]. We thus include the standard ratios used in CAEL: the capital-to-asset ratio; asset quality, as measured by the nonperforming loan ratio; earnings, as measured by the rate of return on assets; and the liquidity ratio. ${ }^{8}$ In addition, we include the percentage of total bank assets in institutions with a capital-to-asset ratio of less than 4 percent. This threshold corresponds with the definition of undercapitalized banks used in the prompt corrective action legislation adopted to force bank supervisors to intervene earlier in financially troubled banks. Each of these variables is constructed from the most recent bank call report data publicly available at the time the forecasts are made.

The results from this specification are reported in Table II. The estimated coefficients on CAMEL5 in the unemployment rate equations are always positive and significant at each forecast 
horizon. The estimated coefficients on CAMEL5 in the inflation equations are negative at each forecast horizon and significant for the four-quarter-ahead forecast. However, among the 40 estimated coefficients on the publicly available bank health variables, many are incorrectly signed and only one is significantly different from zero. These results are consistent with the conclusion that publicly available information on bank health is fully incorporated into private sector forecasts, while the confidential supervisory information contained in CAMEL5 is not. ${ }^{9}$

Since CAMEL5 contains both confidential and nonconfidential information, controlling for the publicly available banking data allows the estimated coefficient on CAMEL5 to better reflect the effects of the confidential component. The results show that it is not the publicly available data on bank health that improves the forecasts. ${ }^{10}$ Furthermore, including the lagged value of CAMEL5, which would assume that the public had all the information contained in the previous period's ratings, even though it did not actually have access to the data, had no effect on the results. Thus, after examining a variety of alternative specifications, we find that it is the confidential supervisory assessment that is critical for the forecast improvement.

The results shown in Tables I and II indicate that confidential bank supervisory information is useful and that it is not exploited by Board staff when they prepare the Greenbook forecasts. ${ }^{11}$ Nonetheless, the supervisory information may be an important determinant of monetary policy if the Federal Reserve Board Governors and Bank Presidents use it to supplement the internal Greenbook forecasts when setting monetary policy. In fact, the organizational structure of the Federal Reserve System is designed to allow diverse views and diverse information sets to be included in FOMC deliberations. The next section addresses this possibility. 


\section{Does Supervisory Information Affect Monetary Policy Actions?}

At each FOMC meeting, the members of the Committee are presented with three possible choices: tighten policy, leave policy unchanged, or loosen policy. Thus, a model of FOMC voting that incorporates these three possible outcomes requires a multinomial logit specification. To identify the equation coefficients, the coefficients on the variables for the no change alternative are set to zero. Thus, equation 2 generates the probability of easing or tightening, relative to leaving policy unchanged, modeled as a function of economic forecasts (EF) and bank supervisory

$$
\operatorname{Prob}(V)_{i, t}=\lambda_{1, i}+\lambda_{2, i} E F_{t}+\lambda_{3, i} C A M E L 5_{t}+\mu_{i, t}
$$

information (CAMEL5):

for $\mathrm{i}=$ ease, tighten.

The data are a panel corresponding to the individual FOMC member votes at each FOMC meeting from 1968 through $1994 .{ }^{12}$ The vector of economic forecasts (EF) is taken from the Greenbook. Thus, the observations for both the votes and the forecasts are at FOMC meeting frequency rather than quarterly. The staff outlook serves as a proxy variable for the individual forecasts of the members of the FOMC, although their actual forecasts may in reality diverge from that of the Greenbook. ${ }^{13}$

Table III provides estimates for variants of equation 2. Column 1 provides results from an estimate that includes the forecasts of the unemployment rate and inflation rate over the next half year (H1), as well as the unemployment rate forecast for the subsequent six-month period $(\mathrm{H} 2)$ and the change in the inflation forecasts between the first half year $(\mathrm{H} 1)$ and the second half year 
$(\mathrm{H} 2){ }^{14}$ For the unemployment rate forecasts, the estimated coefficients for both votes to tighten and votes to ease policy are significant. As expected, the sum of the coefficients on the first and second half-year forecasts indicates that a forecast of a rising unemployment rate is associated with a decreased probability of voting to tighten monetary policy and an increased probability that FOMC members vote to ease policy.

Furthermore, the forecasted change in the inflation rate has the expected effect on monetary policy; when inflation is expected to rise, the probability of tightening monetary policy increases and the probability of easing declines. The estimated coefficient on the forecasted level of the inflation rate has the predicted sign and is significant for tightening policy, although that is not the case for easing policy.

The second column adds CAMEL5, as well as a $(0,1)$ CAMEL dummy variable, to the base equation in Column 1 in order to test the hypothesis that FOMC members judgmentally adjust the staff forecasts to incorporate such information. The CAMEL dummy variable is included since CAMEL ratings do not exist over the entire sample period. This variable has a value of one during the part of the sample for which CAMEL ratings are available (1978-1994). ${ }^{15}$ The estimated coefficients on CAMEL5 are each highly significant, with their signs indicating that monetary policy is reacting in the correct direction. A higher percentage of bank assets held by banks with a CAMEL 5 rating, associated both with unemployment rate forecasts that are too low and inflation rate forecasts that are too high, is associated with a lower probability of tightening and a higher probability of easing.

We conduct a number of specification tests to verify the robustness of the results for CAMEL5. We include money growth over the previous three months as an additional control 
variable, consistent with much of the literature (see, for example, McNees [1986]; Friedman and Kuttner [1996]; and Tootell [1997]). This variable may be relevant because FOMC members may weigh the information content in money growth differently from that incorporated in the Greenbook forecasts. Furthermore, the coefficient estimates in the first two columns suggest that the difference between the first and second half-year forecasts of the unemployment rate may be the appropriate specification. In column 3, we estimate equation 2 with the difference in the two half-year unemployment rate forecasts and the lagged growth rate of M1 as explanatory variables. The estimated coefficients on CAMEL5 for both tightening and easing policy remain highly significant.

To test whether the FOMC is utilizing the confidential component of the CAMEL5 variable, column 4 provides the results from a specification that includes the publicly available data on bank health as additional explanatory variables. ${ }^{16}$ The estimated coefficients on CAMEL5 remain large (in absolute value) and highly significant. This evidence indicates that the confidential CAMEL supervisory data provide information beyond that publicly available that is relevant for FOMC voting behavior. Furthermore, the confidential part of the CAMEL5 variable affects monetary policy in the expected direction; a higher percentage of bank assets in CAMEL 5-rated banks increases the probability of easing and reduces the probability of tightening monetary policy.

While Table III shows that CAMEL5 is a highly statistically significant variable in explaining FOMC votes, the nonlinear specification inherent in logit models does not lend itself to direct economic interpretation. However, we can evaluate how changes in the percentage of bank assets in CAMEL 5-rated banks alter the probability of tightening or easing policy, given that all 
other explanatory variables are at their mean values. Figure I shows these probabilities over a one-standard-deviation range (0.8) above and below the 1.1 mean percentage of bank assets held by CAMEL 5-rated banks. The figure shows that as CAMEL5 rises from 0.3 percent to 1.9 percent, the probability of an FOMC member voting to tighten policy decreases from nearly 40 percent to under 10 percent, while the probability of a vote to ease increases from under 5 percent to 23 percent. Such large changes in the probabilities of easing and tightening, over values well within the range of actual experience, indicate that CAMEL5 is both an economically and a statistically significant determinant of monetary policy. ${ }^{17}$

The importance of CAMEL5 for monetary policy formation is not due just to a small group of FOMC members or to a specific crisis period. Table IV provides results for two sets of alternative specifications, one investigating differences in the voting behavior of Board Governors and Reserve Bank Presidents and the other investigating the sensitivity of the CAMEL5 results to the exclusion of the recent "credit crunch" period in the late 1980s. Distinguishing between Governors and Presidents could be important because the Governors are exposed to supervisory information for the nation as a whole, while Reserve Bank Presidents receive primarily the supervisory information for banks in their District. The results in the first column of Table IV indicate that a Governor is slightly less likely than a Bank President to tighten policy when aggregate bank health is weak. On the other hand, no statistically significant difference is evident in the effect of bank supervisory information on the probability that Governors, compared to Presidents, will vote to ease monetary policy. In general, this result is consistent with the hypothesis that FOMC members share this information. 
It is also possible that the CAMEL5 results are due to a threshold effect, with FOMC members reacting only when banking problems are severe. To test this hypothesis, we examine whether the results emanate only from the "capital crunch" period. We omit the four-year period from 1988 through 1991 that accounts for the largest values of the CAMEL5 variable. The evidence in the second column of Table IV indicates that excluding this subperiod does not eliminate the importance of bank supervisory information in the voting function. The estimated coefficient on CAMEL5 remains highly significant both for votes to tighten policy and for votes to ease. Thus, FOMC members did not respond to bank health only during periods of severe banking problems; FOMC voting was similarly influenced by lesser problems during other time periods.

III. Does the Federal Reserve Need "Hands-On" Bank Supervisory Responsibilities?

The previous two sections provide evidence that confidential supervisory information can improve forecasts of inflation and unemployment rates, and that FOMC members use this information when voting on monetary policy. While this evidence shows that the monetary authority should have access to supervisory information, it does not establish that the Federal Reserve requires direct bank supervisory responsibilities in order to fully exploit this information in the conduct of monetary policy. An important question is whether the Federal Reserve could formulate monetary policy as efficiently if it did not have direct bank supervisory responsibilities.

In the absence of direct supervisory responsibilities, the Federal Reserve could simply request the CAMEL ratings information from the bank regulator. In fact, the Federal Reserve could request any supervisory variable found to be important for the conduct of monetary policy. 
However, the Federal Reserve would need to know which variables are important for their monetary policy deliberations and how to interpret those variables. Specifically, without direct supervisory responsibilities, the Federal Reserve would need to know the importance of CAMEL5 and to understand how the ratings may change over time and vary across types of institutions.

Meeting such requirements might be difficult in practice. First, without ready access to all supervisory data, the Federal Reserve would not be able to ascertain which data are important for the conduct of monetary policy. ${ }^{18}$ Second, the assessment of a bank's health and the information used to make that assessment might depend on the objective function of the agency doing the supervision, limiting the ability of the Federal Reserve to interpret the supervisory agency's data. This difference in objectives could lead to the collection of and emphasis on different bank information. It could also affect the way CAMEL ratings are assigned. To give a specific example, because some banks may have been perceived to be "too big to fail," it is possible that large banks with significant lending exposure in Latin America may have received CAMEL ratings of 4 during the Third World debt crisis when, in fact, their true financial condition warranted a CAMEL rating of 5. If so, in order to effectively utilize the bank supervisory information, the Federal Reserve would have to know not just the aggregate CAMEL5 variable but whether, and for which institutions, forbearance was occurring.

To explore empirically whether standards differ across institutions, we examine whether CAMEL ratings may not have been consistently defined across bank size classes. Specifically, "too big to fail" may manifest itself in a reluctance by regulators to provide the lowest rating, CAMEL 5, and therefore the most stringent enforcement actions, on the largest banks. To test this hypothesis, a variable measuring the percentage of assets in CAMEL 4-rated institutions 
among the largest 50 banks is added to the forecast and voting equations examined in the preceding tables. If forbearance is occurring, a CAMEL 4 rating for a large institution might in many instances contain relevant information, as does a CAMEL 5-rating on institutions for which forbearance is not occurring. The estimated coefficients on these variables should reveal whether the largest banks enjoy "grade inflation" and are actually more troubled than their CAMEL rating would indicate.

Table $\mathrm{V}$ provides the results from estimating the forecast equations with the additional variable. For the unemployment regressions, the estimated coefficients on CAMEL5 remain positive and significant for each of the four forecast horizons. For the inflation regressions, the estimated coefficients on CAMEL5 are negative and significant for each of the forecast horizons. The estimated coefficients on the large-bank CAMEL4 variable are not significant in the unemployment equations, but are significant and correctly signed for each forecast horizon in the inflation equations. These results are consistent with CAMEL 4 ratings at large institutions, like CAMEL 5-rated institutions, conveying information about the economy. ${ }^{19}$ Furthermore, Table VI shows that large-bank CAMEL4 also plays a significant role in monetary policy formulation. ${ }^{20}$ The FOMC is less likely to tighten policy when the percentage of bank assets in CAMEL 4-rated large institutions increases, and the FOMC is more likely to ease when the percentage of the largest 50 banks with CAMEL 4 ratings increases. The results in Table VI suggest that the FOMC's knowledge of the forbearance allowed it to take advantage of the information in largebank CAMEL4 when formulating monetary policy.

To efficiently use the supervisory information, the FOMC must know which of the CAMEL 4-rated institutions were really CAMEL 5s. One possible reason why the coefficient on 
the large-bank CAMEL4 variable is much smaller in absolute value than the coefficient on CAMEL5 is that forbearance at large banks makes the CAMEL4 variable for large banks a noisy signal of big bank distress. Any such forbearance ensures that the CAMEL4 variable for large institutions contains both true CAMEL 5-rated institutions, which add important information to macroeconomic forecasts, and true CAMEL 4-rated banks, which do not. Thus, the effect of the true CAMEL 5-rated institutions in this group is muted by the true CAMEL 4-rated banks also in the category. In this instance, the Federal Reserve's supervisory role may have allowed it to avoid the signal-to-noise problem. While this example is only suggestive, it highlights the need for further research on the benefits of a direct supervisory role by the Federal Reserve.

\section{Conclusion}

This study examines how bank supervisory information is used in the conduct of monetary policy. The supervisory information does not affect monetary policy through the Board staff forecasts, even though it has been shown to reduce the forecast errors for both unemployment and inflation rates. The confidentiality problems associated with wide dissemination of information about individual banks may have limited its use in internal Greenbook forecasts, as well as preventing its use by private forecasters. However, we find that supervisory information does affect monetary policy, and does so in the correct direction. As bank health deteriorates, the probability of tightening monetary policy decreases and the probability of easing increases, as would be desirable given the evidence that higher values of CAMEL5 are associated with Greenbook forecasts that underpredict unemployment rates and overpredict inflation rates. 
The complementarity between supervisory and monetary policy responsibilities has important policy ramifications. Many countries have been considering whether bank supervisory responsibilities are an important function for the central bank or are better assigned to a separate agency. The results in this paper indicate that, at a minimum, the conduct of monetary policy requires full access to supervisory information. Furthermore, for the central bank to exploit this important source of information in the conduct of monetary policy, it must have timely and reliable data. Frequent exams and the plethora of data furnished by banks to the Federal Reserve provide the critical information necessary to monitor current conditions in the banking sector in the United States.

This interaction between bank supervision and the conduct of monetary policy may be even more important in many other countries, particularly developing countries, since their credit markets are usually bank-centered. Given the frequency and severity of recent banking crises in both developing and developed countries, and the greater role that banks play in most of these economies relative to that of banks in the U.S. economy [Caprio and Klingebiel 1996], the lack of reliable data could be a major impediment to utilizing banking information to improve the conduct of monetary policy.

While the timely sharing of information between other bank supervisors and the central bank is certainly possible, the difficulties in sharing highly confidential information, much of which may not be easily quantifiable, might make such arrangements difficult at best. Because the CAMEL5 variable used in this study is only a proxy for the much broader information set about bank health acquired by the Federal Reserve through its bank supervisory role, and because it is not just the extreme changes in bank health that can influence the conduct of monetary policy, 
"hands-on" supervisory experience may be necessary to identify the nuances of changes in bank health that contribute to the effective conduct of monetary policy. Considering the extent of the banking problems experienced recently, it is surprising that many countries have sought to reduce their central bank's involvement in bank supervision.

Boston College and Federal Reserve Bank of Boston

Federal Reserve Bank of Boston

Federal Reserve Bank of Boston 


\section{REFERENCES}

Alesina, Alberto and Lawrence Summers, "Central Bank Independence and Macroeconomic Performance: Some Comparative Evidence," Journal of Money, Credit, and Banking, XXV (1993), 151-162.

Bernanke, Ben S. and Mark Gertler, "Inside the Black Box: The Credit Channel of Monetary Policy Transmission,” Journal of Economic Perspectives, IX (1995), 27-48.

Caprio, Gerard, Jr. and Daniela Klingebiel, "Bank Insolvencies: Cross Country Experiences," The World Bank Policy Research Working Paper No. 1620, July 1996.

Cukierman, Alex, Central Bank Strategy, Credibility, and Independence: Theory and Evidence, (Cambridge, MA: The MIT Press, 1992).

Friedman, Benjamin M. and Kenneth N. Kuttner, "Money, Income, Prices, and Interest Rates," American Economic Review, LXXXII (1992), 472-492.

Friedman, Benjamin M. and Kenneth N. Kuttner, "A Price Target for U.S. Monetary Policy? Lessons from the Experience with Money Growth Targets," Brookings Papers on Economic Activity, No. 1 (1996), 77-146.

Fuhrer, Jeffrey C., "Central Bank Independence and Inflation Targeting: Monetary Policy Paradigms for the Next Millennium?" New England Economic Review, January/February (1997), 19-36.

Hansen, L. P. and R. J. Hodrick, "Forward Exchange Rates As Optimal Predictors of Future Spot Rates: An Econometric Analysis," Journal of Political Economy, LXXXVIII (1980), 829853.

Hubbard, R. Glenn, “Is There a 'Credit Channel' for Monetary Policy?” Federal Reserve Bank of St. Louis Review, May/June (1995), 63-77.

Kashyap, Anil K. and Jeremy C. Stein, "Monetary Policy and Bank Lending," in Monetary Policy, N. Gregory Mankiw, ed. (Chicago, IL: University of Chicago Press, 1994a), 221-256.

Kashyap, Anil K. and Jeremy C. Stein, "The Impact of Monetary Policy on Bank Balance Sheets," Carnegie-Rochester Conference Series on Public Policy, XLII (1994b), 151-195.

Kashyap, Anil K., Jeremy C. Stein, and David W. Wilcox, "Monetary Policy and Credit Conditions: Evidence from the Composition of External Finance," American Economic Review, LXXXIII (1993), 78-98. 
Keane, Michael P. and David E. Runkle, "Testing the Rationality of Price Forecasts: New Evidence from Panel Data," American Economic Review, LXXX (1990), 714-735.

Kydland, Finn and Edward Prescott, "Rules Rather Than Discretion: The Inconsistency of Optimal Plans," Journal of Political Economy, LXXXV (1977), 473-491.

McNees, Stephen K., "Modeling the Fed: A Forward-Looking Monetary Policy Reaction Function," New England Economic Review, November/December (1986), 3-8.

Peek, Joe, and Eric S. Rosengren, "Derivatives Activity at Troubled Banks," Journal of Financial Services Research, XII (1997), 287-392.

Peek, Joe, Eric S. Rosengren, and Geoffrey M. B. Tootell, "Does the Federal Reserve Have an Informational Advantage? You Can Bank on It," Federal Reserve Bank of Boston Working Paper, No. 98-2, April 1998.

Posen, Adam, "Central Bank Independence and Disinflationary Credibility: A Missing Link?" Federal Reserve Bank of New York Staff Reports, No. 1, May 1995.

Romer, Christina D. and David H. Romer, "Federal Reserve Private Information and the Behavior of Interest Rates," NBER Working Paper No. 5692, July 1996.

Theil, Henri, Optimal Decision Rules for Government and Industry, 2nd ed., (Amsterdam: NorthHolland, 1964).

Thomson, James B., "Predicting Bank Failures in the 1980s," Federal Reserve Bank of Cleveland Economic Review, XXVII (1991), 9-20.

Tootell, Geoffrey M. B., "How Far-Sighted Is the FOMC?" New England Economic Review, January/February (1997), 49-65.

Walsh, Carl E., "Optimal Contracts for Central Bankers," American Economic Review, LXXXV (1995), 150-167.

Whalen, Gary and James B. Thomson, "Using Financial Data to Identify Changes in Bank Condition," Federal Reserve Bank of Cleveland Economic Review, XXIV (1988), 17-26. 
Footnotes

1. For example, in testimony before the Committee on Banking, Housing and Urban Affairs of the United States Senate, March 9, 1994, Donald Howard, former Citicorp Chief Financial Officer stated: "If the Federal Reserve were removed from the bank regulation process, would it have any significant impact on its ability to conduct monetary policy? My answer is: Clearly, it would not... It is clear that the primary role of the Federal Reserve is the conduct of monetary policy. That role is so important, I believe carrying out that function should not be diluted even slightly by having any of its resources diverted to any other function, including bank regulation."

2. The traditional CAMEL rating was expanded in 1997 to include sensitivity to market risk. However, the CAMEL rather than the CAMELS rating system was in use throughout our sample period.

3. Unless the information is exchanged fully during FOMC deliberations, Reserve Bank Presidents are likely to have more specific knowledge of banking problems in their own District, but less knowledge of banking problems in other Districts, compared to Board Governors.

4. The CPI is not revised, while the unemployment rate is revised only for updated seasonals, which alter the series only marginally. In contrast, a series such as real GDP includes an advance, a preliminary, and a revised series, which can differ substantially. In addition, benchmark revisions can significantly alter the series. To compare "actual values" to forecasted values, one would need to know which of these alternative estimates should be compared to the forecasts. In addition, when the revisions include a change in base year, the forecasts would be compared to actual values that have been constructed using a different base year.

5. Alternatively, a straightforward test of the hypothesis that the Greenbook fully incorporates the supervisory information can be created by respecifying equation 1, replacing CAMEL5 with (1-GB)*CAMEL5. In this specification, $\alpha_{3}$ would reflect the total rather than the differential effect of CAMEL5 for the Greenbook forecasts. An estimated value for $\alpha_{3}$ that differs significantly from zero would imply that we can reject the hypothesis that the Greenbook forecasts fully incorporate bank supervisory information.

6. Hansen and Hodrick [1980] point out that the errors over longer forecast horizons should follow predictable moving-average processes. In this study, since the forecasts are for nonoverlapping quarters, the moving-average process is not introduced by construction. Rather, the moving-average processes occur because a shock that arises subsequent to the time at which the quarterly forecasts are made is likely to have persistent effects.

7. Romer and Romer [1996] have suggested that central banks generate superior forecasts relative to private forecasters. While confidential bank supervisory information can reduce forecast errors for unemployment and inflation rates, this does not appear to be the source of that 
forecast advantage. Given the Romer and Romer [1996] findings, one might also specify equation 1 with two additional explanatory variables formed by interacting the constant term and the forecast with GB, allowing for the possibility that these two effects as well as that for CAMEL5 may differ for the Greenbook relative to those for private forecasters. However, when this is done, none of the three interaction terms is statistically significant.

8. The nonperforming loan ratio is measured as loans 90 days past due plus nonaccruing loans, divided by total assets. The liquidity ratio includes cash and balances due from depository institutions, securities holdings, and trading assets, divided by total assets. The earnings measure is the annualized quarterly net income divided by average assets. See Whalen and Thomson [1988] for a discussion of the use of financial data to identify bank condition.

9. In fact, the insignificance of the publicly available information is not due to the inclusion in the regression of the CAMEL5 variable. Even when the CAMEL5 variable is dropped from these regressions, the estimated coefficients on the publicly available information are insignifi-cant, which suggests that the publicly known data are efficiently incorporated into the forecasts.

10. This is consistent with the evidence in Peek, Rosengren, and Tootell [1998] that shows that including other macroeconomic variables such as M2, the federal funds rate, and the commercial paper - Treasury bill rate spread as possible proxies for the information contained in supervisory data did not significantly alter the results for CAMEL5.

11. Also, it cannot be rejected that the coefficients on the other banking variables are the same for the commercial forecasters and the Greenbook.

12. The sample is determined by the availability of Greenbook forecasts. These variables were first forecast in 1968. The most recent observations are omitted because the Greenbook outlook is publicly available only with a lag.

13. The $\mu_{\mathrm{i}, \mathrm{t}}$ are assumed to be independently and identically distributed in the estimation results presented in the paper. Relaxing this assumption, either by including fixed effects or allowing the error variance to differ by District Bank, had no effect on the results.

14. Tootell [1997] finds that variables such as lagged inflation rates and lagged real GDP are dominated by forecasts of these variables from the Greenbook. We thus focus on those variables that he found most useful in predicting FOMC votes. Furthermore, the use of the one-year forecast horizons is consistent with his findings for the relevant horizon used by the FOMC.

15. The estimated coefficient on this variable will also reflect any difference in the mean probabilities of easing or tightening policy between the 1978 through 1994 subperiod compared to the 1968 through 1977 subperiod not related to the availability of CAMEL ratings. We also estimated an alternative specification that allowed the CAMEL5 dummy variable to interact with each of the explanatory variables. The estimated coefficient on CAMEL5 remained highly 
significant.

16. The sample has been shortened to begin in 1979:III to correspond to the period for which the data for these additional explanatory variables are available. However, because national banks were the only banks that were required to report nonperforming loan data for the period prior to 1982:IV, we have had to base the earlier observations for the nonperforming loans ratio on the national bank sample. This actually attributes more information to the public than was actually available, since those data were confidential.

17. Note that the actual range of CAMEL5 was from zero to 3.1, so that this figure does not capture the most extreme values of CAMEL5.

18. Furthermore, a bank supervisory agency not directly involved in monetary policy would be unlikely to be able to ascertain which supervisory data would be valuable to the monetary policy authority.

19. The results in Table $\mathrm{V}$ do not originate from the significance of CAMEL4 in general, as the CAMEL4 calculated for all banks does not help explain any of the forecast errors. The results also do not derive from any greater importance in these regressions of large institutions generally, since the CAMEL5 variable calculated for the largest 50 institutions is no more informative about the forecast errors than is CAMEL5 in general. Taken together, these results suggest grade inflation as the source of the significance of the estimated coefficient on large-bank CAMEL4.

20. Because the focus here is on any differences in the effects of CAMEL ratings, large banks compared to other banks and CAMEL 4 ratings compared to CAMEL 5 ratings, we do not include observations prior to 1978 for which CAMEL data are not available. Consequently, column 1 in Table VI presents the basic results for that sample period to make clear the effect of adding the large-bank CAMEL4 variable, shown in column 2. 
TABLE I

Contribution of Confidential Bank Supervisory Information to the Greenbook Relative to Private Forecasts

\begin{tabular}{|c|c|c|c|c|c|c|c|c|}
\hline \multirow[b]{2}{*}{ Variable } & \multicolumn{4}{|c|}{ Unemployment rate } & \multicolumn{4}{|c|}{ Inflation rate } \\
\hline & $1 \mathrm{Q}$ & $2 \mathrm{Q}$ & $3 Q$ & $4 \mathrm{Q}$ & $1 \mathrm{Q}$ & $2 \mathrm{Q}$ & $3 \mathrm{Q}$ & $4 Q$ \\
\hline Constant & $\begin{array}{r}-.001 \\
(.081)\end{array}$ & $\begin{array}{r}.027 \\
(.269)\end{array}$ & $\begin{array}{l}.116 \\
(.493)\end{array}$ & $\begin{array}{r}.305 \\
(.617)\end{array}$ & $\begin{array}{r}.735 \\
(.379)\end{array}$ & $\begin{array}{l}1.154 \\
(.861)\end{array}$ & $\begin{array}{r}1.533 \\
(1.173)\end{array}$ & $\begin{array}{r}2.048 \\
(1.328)\end{array}$ \\
\hline Forecast & $\begin{array}{r}.981^{* *} \\
(.013)\end{array}$ & $\begin{array}{r}.955^{* *} \\
(.039)\end{array}$ & $\begin{array}{r}.931 * * \\
(.071)\end{array}$ & $\begin{array}{r}.903 * * \\
(.087)\end{array}$ & $\begin{array}{r}.920 * * \\
(.040)\end{array}$ & $\begin{array}{r}.896^{* *} \\
(.100)\end{array}$ & $\begin{array}{l}.900 * * \\
(.154)\end{array}$ & $\begin{array}{r}.825 * * \\
(.182)\end{array}$ \\
\hline CAMEL5 & $\begin{array}{r}.090^{* *} \\
(.024)\end{array}$ & $\begin{array}{r}.194 * * \\
(.063)\end{array}$ & $\begin{array}{l}.272^{*} \\
(.109)\end{array}$ & $\begin{array}{l}.283^{*} \\
(.132)\end{array}$ & $\begin{array}{r}-.327 \\
(.181)\end{array}$ & $\begin{array}{r}-.614 \\
(.378)\end{array}$ & $\begin{array}{r}-1.100^{*} \\
(.448)\end{array}$ & $\begin{array}{r}-1.332 * * \\
(.472)\end{array}$ \\
\hline $\begin{array}{l}\text { Greenbook } \\
* \text { CAMEL5 }\end{array}$ & $\begin{array}{r}.009 \\
(.009)\end{array}$ & $\begin{array}{l}-.001 \\
(.022)\end{array}$ & $\begin{array}{r}-.022 \\
(.031)\end{array}$ & $\begin{array}{l}-.035 \\
(.021)\end{array}$ & $\begin{array}{r}.006 \\
(.098)\end{array}$ & $\begin{array}{r}-.064 \\
(.154)\end{array}$ & $\begin{array}{r}.073 \\
(.200)\end{array}$ & $\begin{array}{r}.164 \\
(.217)\end{array}$ \\
\hline
\end{tabular}

The standard errors in the forecast equation are corrected for the appropriate moving average error terms and for contemporaneous correlation across forecasters.

Standard errors are in parentheses.

* Significant at the 5 percent level.

** Significant at the 1 percent level. 


\section{TABLE II}

Contribution of Bank Supervisory Data When Publicly Available Information Is Included

\begin{tabular}{|c|c|c|c|c|c|c|c|c|}
\hline \multirow[b]{2}{*}{ Variable } & \multicolumn{4}{|c|}{ Unemployment rate } & \multicolumn{4}{|c|}{ Inflation rate } \\
\hline & 1Q & $2 Q$ & $3 Q$ & $4 Q$ & $1 \mathrm{Q}$ & $2 \mathrm{Q}$ & $3 Q$ & $4 Q$ \\
\hline Constant & $\begin{array}{r}-1.125 * \\
(.474)\end{array}$ & $\begin{array}{r}-2.363 \\
(1.559)\end{array}$ & $\begin{array}{r}-4.032 \\
(2.812)\end{array}$ & $\begin{array}{r}-4.250 \\
(3.427)\end{array}$ & $\begin{array}{r}3.805 \\
(3.807)\end{array}$ & $\begin{array}{r}11.465 \\
(7.311)\end{array}$ & $\begin{array}{c}16.183 \\
(8.610)\end{array}$ & $\begin{array}{r}11.660 \\
(8.830)\end{array}$ \\
\hline Forecast & $\begin{array}{r}.959 * * \\
(.017)\end{array}$ & $\begin{array}{r}.865 * * \\
(.059)\end{array}$ & $\begin{array}{l}.711 * * \\
(.107)\end{array}$ & $\begin{array}{l}.590 * * \\
(.139)\end{array}$ & $\begin{array}{c}.873 * * \\
(.049)\end{array}$ & $\begin{array}{l}.852 * * \\
(.122)\end{array}$ & $\begin{array}{r}.816^{* * *} \\
(.199)\end{array}$ & $\begin{array}{r}.689 * * \\
(.217)\end{array}$ \\
\hline CAMEL5 & $\begin{array}{r}.138 * * \\
(.032)\end{array}$ & $\begin{array}{c}.280 * * \\
(.101)\end{array}$ & $\begin{array}{r}.454 * * \\
(.174)\end{array}$ & $\begin{array}{l}.549 * \\
(.219)\end{array}$ & $\begin{array}{r}-.378 \\
(.260)\end{array}$ & $\begin{array}{r}-.517 \\
(.498)\end{array}$ & $\begin{array}{c}-.767 \\
(.575)\end{array}$ & $\begin{array}{r}-1.143^{*} \\
(.552)\end{array}$ \\
\hline Capital/assets & $\begin{array}{r}.007 \\
(.049)\end{array}$ & $\begin{array}{r}-.078 \\
(.158)\end{array}$ & $\begin{array}{r}-.093 \\
(.282)\end{array}$ & $\begin{array}{r}.029 \\
(.357)\end{array}$ & $\begin{array}{r}-.827 \\
(.427)\end{array}$ & $\begin{array}{r}-.580 \\
(.816)\end{array}$ & $\begin{array}{r}.437 \\
(.943)\end{array}$ & $\begin{array}{r}-.441 \\
(.943)\end{array}$ \\
\hline NPL/assets & $\begin{array}{l}.127 * \\
(.063)\end{array}$ & $\begin{array}{r}.373 \\
(.198)\end{array}$ & $\begin{array}{r}.555 \\
(.349)\end{array}$ & $\begin{array}{r}.409 \\
(.434)\end{array}$ & $\begin{array}{r}.262 \\
(.524)\end{array}$ & $\begin{array}{l}-.338 \\
(.964)\end{array}$ & $\begin{array}{l}-1.192 \\
(1.083)\end{array}$ & $\begin{array}{c}.056 \\
(1.025)\end{array}$ \\
\hline Return on assets & $\begin{array}{r}.053 \\
(.047)\end{array}$ & $\begin{array}{r}.127 \\
(.125)\end{array}$ & $\begin{array}{r}.221 \\
(.201)\end{array}$ & $\begin{array}{r}.190 \\
(.255)\end{array}$ & $\begin{array}{r}.086 \\
(.414)\end{array}$ & $\begin{array}{r}.291 \\
(.682)\end{array}$ & $\begin{array}{r}-.688 \\
(.718)\end{array}$ & $\begin{array}{r}-.269 \\
(.706)\end{array}$ \\
\hline Liquid assets/assets & $\begin{array}{r}.026 \\
(.016)\end{array}$ & $\begin{array}{r}.075 \\
(.049)\end{array}$ & $\begin{array}{r}.135 \\
(.085)\end{array}$ & $\begin{array}{r}.140 \\
(.108)\end{array}$ & $\begin{array}{r}.066 \\
(.106)\end{array}$ & $\begin{array}{r}-.174 \\
(.203)\end{array}$ & $\begin{array}{r}-.306 \\
(.231)\end{array}$ & $\begin{array}{r}-.184 \\
(.229)\end{array}$ \\
\hline Capital/assets < $4 \%$ & $\begin{array}{r}.003 \\
(.005)\end{array}$ & $\begin{array}{r}.005 \\
(.015)\end{array}$ & $\begin{array}{r}.004 \\
(.026)\end{array}$ & $\begin{array}{r}.034 \\
(.033)\end{array}$ & $\begin{array}{r}-.049 \\
(.041)\end{array}$ & $\begin{array}{r}.002 \\
(.077)\end{array}$ & $\begin{array}{r}.102 \\
(.087)\end{array}$ & $\begin{array}{r}-.002 \\
(.086)\end{array}$ \\
\hline
\end{tabular}

The standard errors in the forecast equation are corrected for the appropriate moving average error terms and for contemporaneous correlation across forecasters.

Standard errors are in parentheses.

* Significant at the 5 percent level.

**Significant at the 1 percent level. 


\section{TABLE III}

Contribution of Confidential Bank Supervisory Information to Monetary Policy Decisions

Estimation Method: Multinomial Logit, 1968-1994

Base, No CAMEL Base with CAMEL Extended with CAMEL Include Other Banking

(1)

(2)

Variables

(4)

Probability of tightening

\begin{tabular}{|c|c|c|c|c|}
\hline Constant & $\begin{array}{l}-.288 \\
(.291)\end{array}$ & $\begin{array}{r}.132 \\
(.300)\end{array}$ & $\begin{array}{r}-1.536 * * \\
(.202)\end{array}$ & $\begin{array}{r}10.051 * * \\
(3.358)\end{array}$ \\
\hline Forecast unemployment H1 & $\begin{array}{r}.793 * * \\
(.150)\end{array}$ & $\begin{array}{r}.989 * * \\
(.161)\end{array}$ & & \\
\hline Forecast unemployment $\mathrm{H} 2$ & $\begin{array}{r}-1.198^{* *} \\
(.169)\end{array}$ & $\begin{array}{r}-1.338 * * \\
(.183)\end{array}$ & & \\
\hline$\Delta$ Unemployment forecasts & & & $\begin{array}{r}-.660 * * \\
(.155)\end{array}$ & $\begin{array}{r}-.028 \\
(.371)\end{array}$ \\
\hline Forecast inflation $\mathrm{H} 1$ & $\begin{array}{r}.373 * * \\
(.036)\end{array}$ & $\begin{array}{r}.196 * * \\
(.039)\end{array}$ & $\begin{array}{l}.066^{*} \\
(.033)\end{array}$ & $\begin{array}{r}-.235^{*} \\
(.119)\end{array}$ \\
\hline Change in inflation forecast & $\begin{array}{r}.329 * * \\
(.076)\end{array}$ & $\begin{array}{r}.134 \\
(.084)\end{array}$ & $\begin{array}{r}.103 \\
(.081)\end{array}$ & $\begin{array}{r}.002 \\
(.151)\end{array}$ \\
\hline CAMEL 5 & & $\begin{array}{r}-1.049 * * \\
(.117)\end{array}$ & $\begin{array}{r}-1.242 * * \\
(.119)\end{array}$ & $\begin{array}{r}-.842 * * \\
(.273)\end{array}$ \\
\hline Dummy 1978-94 & & $\begin{array}{r}1.177 * * \\
(.150)\end{array}$ & $\begin{array}{r}1.036^{* *} \\
(.150)\end{array}$ & \\
\hline Lagged money growth & & & $\begin{array}{r}.029 * * \\
(.011)\end{array}$ & $\begin{array}{r}.021 \\
(.013)\end{array}$ \\
\hline Capital/assets & & & & $\begin{array}{r}.360 \\
(.316)\end{array}$ \\
\hline NPL/assets & & & & $\begin{array}{r}-3.108 * * \\
(.449)\end{array}$ \\
\hline Return on assets & & & & $\begin{array}{r}.440 \\
(.330)\end{array}$ \\
\hline Liquid assets/assets & & & & $\begin{array}{r}-.233 * * \\
(.076)\end{array}$ \\
\hline Capital/assets $<4 \%$ & & & & $\begin{array}{r}.204 * * \\
(.031)\end{array}$ \\
\hline
\end{tabular}

Probability of easing

\begin{tabular}{lrrrr|}
\hline Constant & $-.887^{* *}$ & $-1.696^{* *}$ & -.041 & $16.186^{* *}$ \\
& $(.268)$ & $(.293)$ & $(.227)$ & \\
\hline Forecast unemployment H1 & $-1.719^{* *}$ & $-2.094^{* *}$ & & \\
& $(.174)$ & $(.178)$ & & \\
Forecast unemployment H2 & $1.844^{* *}$ & $2.363^{* *}$ & & \\
& $(.192)$ & $(.202)$ & & $2.369^{* *}$ \\
\hline Unemployment forecasts & & & $1.474^{* *}$ & $(.170)$ \\
Forecast inflation H1 & & & $-.145^{* *}$ & $-.366^{* *}$ \\
\hline Change in inflation forecast & $.299^{* *}$ & $-.214^{* *}$ & $(.042)$ & $(.127)$ \\
& $(.038)$ & $(.044)$ & -.113 & $-.805^{* *}$ \\
& $-.398^{* *}$ & .114 & $(.098)$ & $(.180)$
\end{tabular}


TABLE III

Contribution of Confidential Bank Supervisory Information to Monetary Policy Decisions

Estimation Method: Multinomial Logit, 1968-1994

Base, No CAMEL Base with CAMEL Extended with CAMEL Include Other Banking

(1)

(2)

(3)

Variables

(4)

\begin{tabular}{|c|c|c|c|c|}
\hline CAMEL 5 & & $\begin{array}{r}.891 * * \\
(.111)\end{array}$ & $\begin{array}{r}.818 * * \\
(.106)\end{array}$ & $\begin{array}{r}.793 * * \\
(.163)\end{array}$ \\
\hline Dummy 1978-94 & & $\begin{array}{r}-2.127 * * \\
(.221)\end{array}$ & $\begin{array}{r}-1.509 * * \\
(.206)\end{array}$ & \\
\hline Lagged money growth & & & $\begin{array}{r}-.071 * * \\
(.014)\end{array}$ & $\begin{array}{r}-.069 * * \\
(.018)\end{array}$ \\
\hline Capital/assets & & & & $\begin{array}{c}-1.797 * * \\
(.427)\end{array}$ \\
\hline NPL/assets & & & & $\begin{array}{c}-1.409 * * \\
(.409)\end{array}$ \\
\hline Return on assets & & & & $\begin{array}{c}-.608 * * \\
(.228)\end{array}$ \\
\hline Liquid assets/assets & & & & $\begin{array}{l}-.058 \\
(.073)\end{array}$ \\
\hline Capital/assets $<4 \%$ & & & & $\begin{array}{l}-.021 \\
(.032)\end{array}$ \\
\hline Number of observations & 2703 & 2703 & 2703 & 1453 \\
\hline Log likelihood & -2386.55 & -2264.41 & -2290.48 & 1073.98 \\
\hline
\end{tabular}

Standard errors are in parentheses.

* Significant at the 5 percent level.

**Significant at the 1 percent level. 


\section{TABLE IV}

Contribution of Confidential Bank Supervisory Information to Monetary Policy Decisions for Alternative Specifications Estimation Method: Multinomial Logit, 1968-1994

\begin{tabular}{|c|c|c|}
\hline \multirow[b]{2}{*}{ Probability of tightening } & Governors vs Presidents & \multirow[t]{2}{*}{ Excluding 1988-1991 } \\
\hline & & \\
\hline Constant & $\begin{array}{r}-1.533 * * \\
(.202)\end{array}$ & $\begin{array}{r}-1.537 * * \\
(.205)\end{array}$ \\
\hline$\Delta$ Unemployment forecasts & $\begin{array}{r}-.662 * * \\
(.155)\end{array}$ & $\begin{array}{r}-.672 * * \\
(.158)\end{array}$ \\
\hline Forecast inflation $\mathrm{H} 1$ & $\begin{array}{r}.065 \\
(.034)\end{array}$ & $\begin{array}{r}.054 \\
(.034)\end{array}$ \\
\hline Change in inflation forecast & $\begin{array}{r}.102 \\
(.082)\end{array}$ & $\begin{array}{r}.041 \\
(.084)\end{array}$ \\
\hline Lagged money growth & $\begin{array}{r}.030 * * \\
(.011)\end{array}$ & $\begin{array}{r}.036 * * \\
(.012)\end{array}$ \\
\hline CAMEL 5 & $\begin{array}{r}-1.402 * * \\
(.142)\end{array}$ & $\begin{array}{r}-1.339 * * \\
(.143)\end{array}$ \\
\hline CAMEL $5 *$ president & $\begin{array}{l}.314^{*} \\
(.135)\end{array}$ & \\
\hline Dummy 1978-94 & $\begin{array}{r}1.045 * * \\
(.150)\end{array}$ & $\begin{array}{r}1.064 * * \\
(.155)\end{array}$ \\
\hline \multicolumn{3}{|l|}{ Probability of easing } \\
\hline Constant & $\begin{array}{r}-040 \\
(.227)\end{array}$ & $\begin{array}{c}-.126 \\
(.236)\end{array}$ \\
\hline$\Delta$ Unemployment forecasts & $\begin{array}{r}1.475 * * \\
(.170)\end{array}$ & $\begin{array}{r}1.423 * * \\
(.183)\end{array}$ \\
\hline Forecast inflation $\mathrm{H} 1$ & $\begin{array}{r}-.145 * * \\
(.042)\end{array}$ & $\begin{array}{r}-.129 * * \\
(.043)\end{array}$ \\
\hline Change in inflation forecast & $\begin{array}{l}-.112 \\
(.098)\end{array}$ & $\begin{array}{l}-.127 \\
(.102)\end{array}$ \\
\hline Lagged money growth & $\begin{array}{r}-.071 * * \\
(.014)\end{array}$ & $\begin{array}{r}-.070 * * \\
(.015)\end{array}$ \\
\hline CAMEL 5 & $\begin{array}{r}.847 * * \\
(.113)\end{array}$ & $\begin{array}{r}1.040 * * \\
(.131)\end{array}$ \\
\hline CAMEL $5 *$ president & $\begin{array}{r}-.063 \\
(.090)\end{array}$ & \\
\hline Dummy 1978-94 & $\begin{array}{r}-1.512 * * \\
(.206)\end{array}$ & $\begin{array}{r}-1.592 * * \\
(.221)\end{array}$ \\
\hline Number of observations & 2703 & 2350 \\
\hline Log likelihood & -2287.30 & -2023.28 \\
\hline
\end{tabular}

Standard errors are in parentheses.

* Significant at the 5 percent level.

**Significant at the 1 percent level. 


\section{TABLE V}

Contribution of Confidential Bank Supervisory Information to Forecasts: Large Bank Differences

\begin{tabular}{|c|c|c|c|c|c|c|c|c|}
\hline \multirow[b]{2}{*}{ Variable } & \multicolumn{4}{|c|}{ Unemployment rate } & \multicolumn{4}{|c|}{ Inflation rate } \\
\hline & $1 Q$ & $2 Q$ & $3 Q$ & $4 Q$ & $1 Q$ & $2 Q$ & $3 Q$ & $4 Q$ \\
\hline Constant & $\begin{array}{r}-.012 \\
(.082)\end{array}$ & $\begin{array}{r}.088 \\
(.283)\end{array}$ & $\begin{array}{r}.352 \\
(.519)\end{array}$ & $\begin{array}{r}.787 \\
(.653)\end{array}$ & $\begin{array}{r}1.670 * * \\
(.536)\end{array}$ & $\begin{array}{r}3.427 * * \\
(1.147)\end{array}$ & $\begin{array}{r}5.409 * * \\
(1.575)\end{array}$ & $\begin{array}{r}6.515 * * \\
(1.775)\end{array}$ \\
\hline Forecast & $\begin{array}{r}.482^{* * *} \\
(.013)\end{array}$ & $\begin{array}{c}.950 * * \\
(.040)\end{array}$ & $\begin{array}{r}.910 * * \\
(.072)\end{array}$ & $\begin{array}{r}.859 * * \\
(.089)\end{array}$ & $\begin{array}{l}.842 * * \\
(.051)\end{array}$ & $\begin{array}{r}.687 * * \\
(.119)\end{array}$ & $\begin{array}{r}.491 * * \\
(.186)\end{array}$ & $\begin{array}{r}.329 \\
(.219)\end{array}$ \\
\hline Large CAMEL4 & $\begin{array}{r}.001 \\
(.003)\end{array}$ & $\begin{array}{r}-.005 \\
(.008)\end{array}$ & $\begin{array}{r}-.017 \\
(.014)\end{array}$ & $\begin{array}{r}-.030 \\
(.017)\end{array}$ & $\begin{array}{r}-.061 * \\
(.026)\end{array}$ & $\begin{array}{l}-.129 * \\
(.052)\end{array}$ & $\begin{array}{r}-.191 * * \\
(.064)\end{array}$ & $\begin{array}{r}-.204 * * \\
(.069)\end{array}$ \\
\hline CAMEL5 & $\begin{array}{r}.092 * * \\
(.024)\end{array}$ & $\begin{array}{r}.198 * * \\
(.063)\end{array}$ & $\begin{array}{r}.279 * * \\
(.108)\end{array}$ & $\begin{array}{l}.296^{*} \\
(.130)\end{array}$ & $\begin{array}{l}-.444 * \\
(.189)\end{array}$ & $\begin{array}{l}-.928 * \\
(.378)\end{array}$ & $\begin{array}{r}-1.512^{* *} \\
(.439)\end{array}$ & $\begin{array}{r}-1.770 * * \\
(.464)\end{array}$ \\
\hline
\end{tabular}

The standard errors in the forecast equation are corrected for the appropriate moving average error terms and for contemporaneous correlation across forecasters.

Standard errors are in parentheses.

* Significant at the 5 percent level.

**Significant at the 1 percent level. 


\begin{tabular}{|c|c|c|}
\hline \multicolumn{3}{|c|}{$\begin{array}{l}\text { TABLE VI } \\
\text { Contribution of Confidential Bank } \\
\text { Decisions: Large Bank Differences }\end{array}$} \\
\hline \multirow{2}{*}{ Probability of tightening } & 1978-1994 & Including Large CAMEL 4 \\
\hline & & \\
\hline Constant & $\begin{array}{r}.590 \\
(.305)\end{array}$ & $\begin{array}{r}2.729 * * \\
(.575)\end{array}$ \\
\hline$\triangle$ Unemployment forecasts & $\begin{array}{r}-1.448^{* *} \\
(.251)\end{array}$ & $\begin{array}{r}-.896 * * \\
(.264)\end{array}$ \\
\hline Forecast inflation $\mathrm{H} 1$ & $\begin{array}{r}-.160^{* *} \\
(.046)\end{array}$ & $\begin{array}{r}-.279 * * \\
(.079)\end{array}$ \\
\hline Change in inflation forecast & $\begin{array}{r}.209 \\
(.111)\end{array}$ & $\begin{array}{r}.071 \\
(.115)\end{array}$ \\
\hline Lagged money growth & $\begin{array}{l}-.004 \\
(.012)\end{array}$ & $\begin{array}{l}.029^{*} \\
(.013)\end{array}$ \\
\hline Large CAMEL4 & & $\begin{array}{r}-.153 * * \\
(.022)\end{array}$ \\
\hline CAMEL5 & $\begin{array}{r}-1.307 * * \\
(.125) \\
\end{array}$ & $\begin{array}{r}-1.682 * * \\
(.146) \\
\end{array}$ \\
\hline Probability of easing & & \\
\hline Constant & $\begin{array}{r}-2.254 * * \\
(.500)\end{array}$ & $\begin{array}{r}-3.020 * * \\
(.586)\end{array}$ \\
\hline$\triangle$ Unemployment forecasts & $\begin{array}{r}1.545^{* * *} \\
(.324)\end{array}$ & $\begin{array}{r}1.582 * * \\
(.331)\end{array}$ \\
\hline Forecast inflation $\mathrm{H} 1$ & $\begin{array}{r}-.053 \\
(.077)\end{array}$ & $\begin{array}{r}.034 \\
(.086)\end{array}$ \\
\hline Change in inflation forecast & $\begin{array}{r}-.170 \\
(.142)\end{array}$ & $\begin{array}{l}-.163 \\
(.142)\end{array}$ \\
\hline Lagged money growth & $\begin{array}{r}-.067 * * \\
(.016)\end{array}$ & $\begin{array}{r}-.080 * * \\
(.017)\end{array}$ \\
\hline Large CAMEL4 & & $\begin{array}{r}.050 * * \\
(.019)\end{array}$ \\
\hline CAMEL5 & $\begin{array}{r}.952 * * \\
(.119)\end{array}$ & $\begin{array}{r}.988^{* *} \\
(.118)\end{array}$ \\
\hline Number of observations & 1600 & 1600 \\
\hline Log likelihood & 1253.85 & 1222.50 \\
\hline
\end{tabular}

Standard errors are in parentheses.

* Significant at the 5 percent level.

**Significant at the 1 percent level. 


\section{Figure I}

The Effect of CAMEL5 on Voting Probabilities

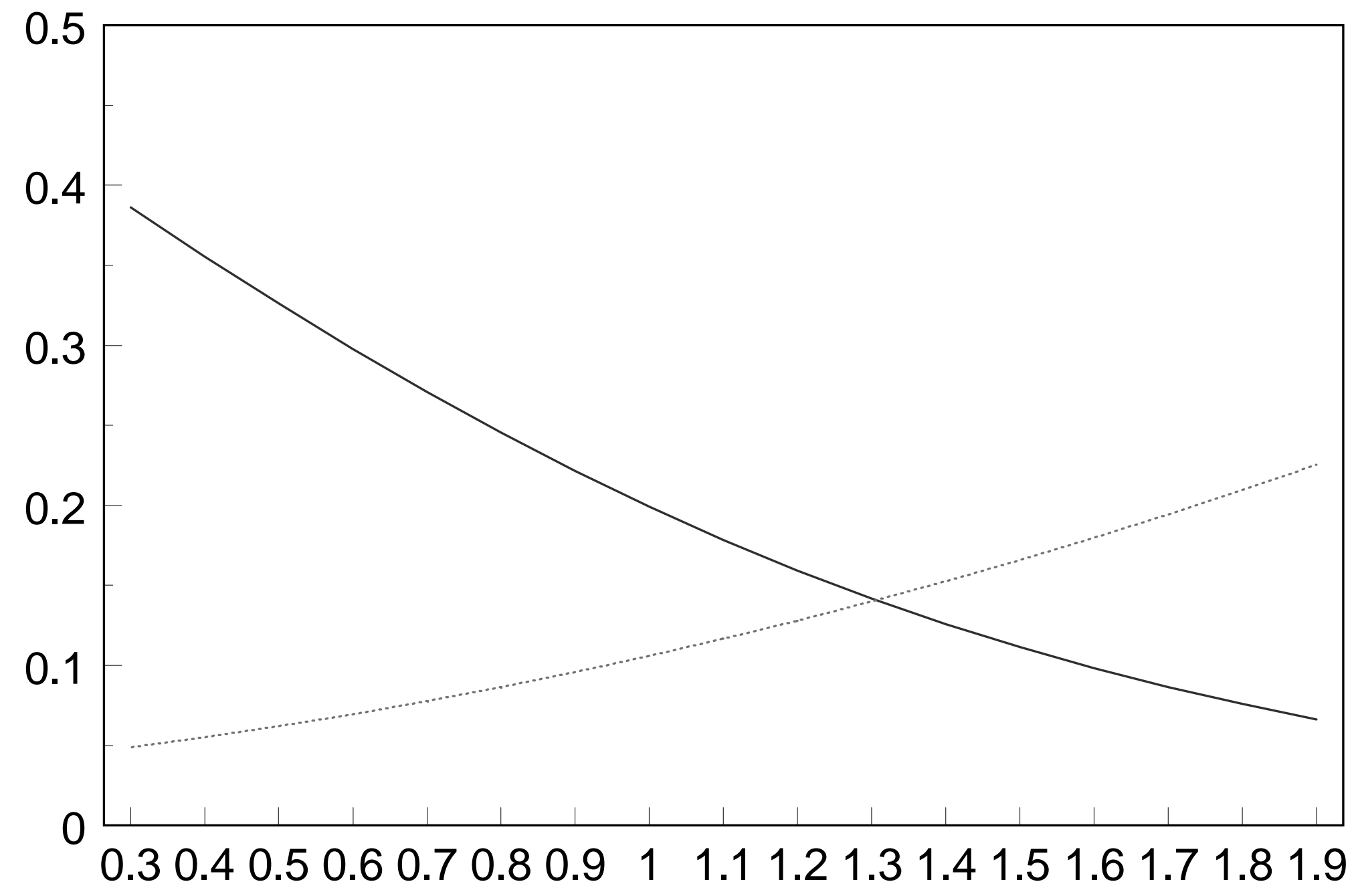

PTighten

PLoosen 